\title{
Heidegger's ontic relatedness: Pros ti and Mitsein
}

\author{
Parentesco ôntico em Heidegger: Pros ti e Mitsein
}

\author{
Laura Candiotto*
}

Universidade de Edimburgo, Escócia, UK

\section{Abstract}

Relational structure is a primitive notion of Heidegger's Dasein. By analyzing the concept of pros-ti as it emerges from the Heidegger's 1924 course dedicated to Plato's Sophist, I outline the Platonic and Aristotelic roots of Heideggerian Mitsein. Arguably the Mitsein makes explicit the instances of the pros ti - in other words, the instances of Aristotle's concept of relatedness/intentionality that Heidegger ascribes to Plato's heteron - but giving them an existential value, having Heidegger pursued the shift from realism to phenomenologyexistentialism. The article concludes by emphasizing the relevance of these themes for social ontology.

Keywords: Heidegger. Pros ti. Mitsein. Metaphysics of relations. Social ontology.

* LC: Pós - doutora em Filosofia, e-mail: laura.candiotto@ed.ac.uk 


\section{Resumo}

A estrutura relacional é uma noção primitiva do Dasein de Heidegger. Ao analisar o conceito de pros-ti como emerge de curso de Heidegger, de 1924, dedicado ao Sophist de Platão, eu delineio as raízes platônicas e aristotélicas do Mitsein heideggeriano. Sem dúvida o Mitsein explicita as instâncias do pros ti - em outras palavras, as instâncias do conceito de parentesco/intencionalidade de Aristóteles, que Heidegger atribui a heteron de Platão - mas dando-Ihes um valor existencial, tendo Heidegger perseguido a mudança do realismo para a fenomenologia-existencialismo. $O$ artigo conclui enfatizando a relevância destes temas para ontologia social.

Palavras-chave: Heidegger. Pros ti. Mitsein. Metafísica das relações. Ontologia social.

\section{Introducción}

Heidegger's lectures on the Sophist are of great importance not only because through their analysis it is possible to grasp the genesis of some central ideas of Sein und Zeit, but also insofar as the formulation of such ideas - which takes place through Heidegger's reading and phenomenological interpretation of books IV and VI of Aristotle's Nicomachean Ethics and of Plato's Sophist - enables us to outline defining features of key concepts of Sein und Zeit, in particular on Heidegger's Mitsein. My main thesis is that the Mitsein brings to light instances of the pros ti, i.e. the Aristotelic concept of relatedness/intentionality that Heidegger ascribes to Plato's heteron as well, emphatizing the existential value of relatedness, freeing it from the mere ontological grounding.

Nevertheless, ontological inquiries are not denied: for Heidegger the concept of pros ti is strictly connected, within the Platonic context, to the determination of dynamis, to be understood as relational power, and distinguished from kinesis, movement. The ability of weaving relations can be considered therefore as the cipher characterizing the Dasein in its relation with intra-worldness: temporality needs to be intended as possibility/power/capability. 
In the first place, I will approach the Platonic text to outline those features which, in my perspective, are central for the constitution of the Dasein. Subsequently, I will discuss the specific feature of relation expressed by the Mitsein, underlining the differences between the model of relatedness expressed by the pros $t i$ and that expressed by the Mitsein. The existential valence of the Mitsein will enable a further investigation, focusing on the concept of inauthentic relations: by following this avenue of research, I will finally advance a personal proposal within the field of social ontology.

\section{Plato's Sophist: Being as heteron}

In the ontological digression of the Sophist, Plato, through the Eleatic visitor, studies the relations among the most important kinds: Being, Change, Changelessness, Sameness and Difference. Moreover, he establishes the difference between the concept of absolute non-being, which can be neither said nor thought, and the concept of relative non-being, that in some sense also "is" .

Being is defined as dynamis, the capacity of weaving bonds - in other words, relationships among the elements. In this perspective, the concept of heteron is essential, as it defines the vehicle through which being, by building relations through a dynamic movement, becomes an orderly and connected plurality. This type of Being is different from Parmenides' stable Being, characterized by self-identity: it is a Being which tends to approach others. ${ }^{2}$

The heteron is a very particular kind as it absolves the function of connecting the kinds together: "we shall say that pervades them all" 3 . Plato's description of the specific relations among the kinds aims at explaining how certain things can be related, others not. However, relationality represents the pure essence of things: whilst everything is what it

1 Plato, Soph. 257 b1.

2 For a deeply analysis of the Plato's ontology or relations, please see L. Candiotto, "Platone e la metafisica delle relazioni", in L. Candiotto (ed.), Senza dualismo. Nuovi percorsi nella filosofia di Platone, Mimesis, Milano-Udine 2015, p. 73-93.

3 Plato, Soph. 255 e 3 - 4. 
is and, at the same time, is different from other things ${ }^{4}$, something could not even be itself if it was not related to something else. Therefore, identity and difference complement each other in the constitution of things.

I explained elsewhere ${ }^{5}$ how negation is the specific form of relation expressed by the heteron. In other words, heteron is the 'relative being' whose modality of relationship occurs through a 'not'. This 'not' expresses thus a specific process of differentiation: identity is reached via negationis. In order to underline the centrality of the relational aspect, "being not" could be translated (from a theoretical point of view) as 'being with': negation transfigures from discrete opposition into complementary antithesis ${ }^{6}$.

This shift represents the key point of Heidegger's interpretation of the negation characterizing Plato's heteron. It is not possible to elaborate further on this aspect of the heteron here, however, as we shall see, it plays a central role in the determination of the Mitsein itself.

\section{Heidegger's Sophist: the heteron as pros ti}

For Heidegger it is necessary to proceed hermeneutically from the clear to the obscure: the understanding of Plato builds upon the reading of Aristotle ${ }^{7}$. Heidegger could underline the intentional aspect of relations deployed in the Platonic dialogue thanks to the study of Aristotle, which he carried out during the first part of the lecture course mentioned in the first section of this paper. Building on this

\footnotetext{
4 N. L. Cordero, "Introduction". in N. L. Cordero (ed.), Platon: Le Sophiste, GF Flammarion, Paris 1993, p. 11-65, p. 25.

5 L. Candiotto, "The heteron as relational being. Heidegger's interpretation of Plato's Sophist 257b-259d"; D. De Brasi, M. Fuchs (ed.), Sophistes. Der platonische Dialog und Heideggers Marburger Vorlesung (WS 1924/25), Duncker \& Humblot Verlag, Berlin 2016 (forthcoming); L. Candiotto, "II negativo è anche positivo. La trasfigurazione della negazione tra immediatezza e mediazione", L. Marcato (ed.), Forme della negazione. Un percorso interculturale tra Oriente e Occidente, Mimesis, Milano 2015, p. 161-178.

6 For more information about the role of negation in Plato's philosophy See D. O'Brien, Le non-être. Deux études sur le Sophiste de Platon, Akademia Verlag, Sankt Augustin: 1995, and M. Dixsaut, "La negation, le non-être et l'autre dans le Sophiste", in P. Aubenque, M. Narcy (eds), Etudes sur le Sophiste de Platon, Bibliopolis, Roma 1991, p. 167-213.

7 Heidegger, Platon: Sophistes, GA IX, p. 10-12.
} 
theoretical trajectory, Heidegger establishes a link between the nature of the Different and Being as dynamis.

The dynamis of Being should be understood as pros ti, i.e. as an ontological attitude directed to the establishment of relations ${ }^{8}$. This attitude is captured by the meaning of Being as heteron (Difference). Heidegger defines the heteron as pros ti: relational intentionality. Relations are logical and linguistic but also ontological. Logos means relation (Beziehung), Being is not one but many. Accordingly, reality has a dialectical structure: it is characterized by the capacity (dynamis) to take together (koinonein) different parts as related (pros ti).

Relation connects two different things but such things can be different only in virtue of their relation (Soph. $255 \mathrm{~d} 1$ ). In other words, “... we find that what is other must of necessity be what it is in relation to some other" (Soph. 255 d 6-7) ${ }^{9}$. Accordingly, identity is guaranteed by difference from what is different: $\mathrm{A}$ is A because it is different from A. Difference itself, by excluding the identity between terms, guarantees the identity of every-thing. Through this trajectory, Heidegger recovers the centrality of the pros t $i$ qua relatedness: the heteron is the non being of something in the sense of being what is "different from" (heteron pros) that something. In this perspective, Heidegger emphasizes that the "not" is not to be understood as the empty field of an arbitrary nothingness, but as heteron allou tinos, the 'not' of an 'other' (p. 391). As we shall see, thanks to this process it will be possible to understand otherness as a concrete other.

I agree with Andrea Le Moli who stresses that the centrality of the heteron as pros $t i$ is the key point of Heidegger's interpretation of the Sophist ${ }^{10}$. He emphasizes how this approach to otherness produces a radical transformation of the concept of einai, which implies the fundamental capacity of weaving relations and establishing communication among the several kinds entering in its constitution.

8 D. Ambuel, Image and Paradigm in Plato's Sophist, Parmenides Publishing, Las Vegas 2006, p. 113-117.

9 The Dialogues of Plato, translated by Benjamin Jowett, V4 of 5, 3rd edition, 1892.

10 A. Le Moli, Heidegger e Platone. Essere, Relazione, Differenza, Vita e Pensiero, Milano 2002, p. $26,45$. 
For Heidegger, the establishment of relations is animated by the heteron rather than by the kinesis: 'I emphasize explicitly that the heteron, not the kinesis, is the dialectical theme, although the latter is spoken of constantly in what follows. Kinesis is only the guideline for showing the universal presence of the heteron throughout all gene' (p. 379).

The image of temporality emerging from the Heideggerian interpretation of the Sophist, is not that of a physical becoming but one based on the possibility of relation. Such temporality is intrinsic to being itself as heteron. It is important to emphasize how these reflections represent some of the fundamental traits of Heidegger's thought in Sein und Zeit: the interpretation of the pros ti enabled Heidegger to grasp not only the relational structure of intra-worldness, but also the fundamental nexus between being and time (temporality being intended here as possibility).

\section{The intentional structure of Dasein}

The complementarity existing within relations implies the fact that the relation itself is not a bystander between two terms, but the very being of such terms establishing both their identity and mutual difference. There cannot be an A without a B: there is only an A with a $\mathrm{B}$, and a B with an A.

In this perspective, identity does not configure a tautology tout court (as maintained by Parmenidean logic), but implies the establishment of a relation with difference. Insofar as communication among the kinds is characterized by an ordered structure, it becomes possible to think not only a new meaning of non-being but also a diversity and new meaning of identity. Arguably, Plato aimed at proposing a new meaning for the concepts of identity and difference by enframing them within an ontology of relations.

The passage from the Sophist to Sein und Zeit is accomplished through Husserl's phenomenology. By applying a phenomenological method to the reading of Plato and Aristotle, Heidegger is able to individuate a relational structure which becomes intentional with Husserl, 
thus inherent to the human world. A radical difference emerges within the continuity between the Sophist and Sein und Zeit - a difference which can be arguably considered as a cipher of the wider discontinuity between ancient and modern philosophy: Heidegger's Mitsein does not refer anymore to pure relatedness among objects at an ontological level but to the relational nexus with the other which constitutes human experience. Obviously, Heidegger's philosophy still aims to operate at an ontological level, however, in order to do so, it will not use the "realist" ontology characterizing classical thought - Heidegger will rather argue that experience itself is what constitutes essence: "Das 'Wesen' des Daseins liegt in seiner Existenz" ${ }^{11}$.

It is possible to notice here the intentional structure of Dasein: that which comprehends, reaches out essentially towards the comprehended; through this reaching out it grasps its own intimate structure. That which comprehends is, for its own nature, striving towards what is other than itself, it is thus a $\mathrm{Zu}$-Sein. Due to this structural mediation between what comprehends and what is comprehended the Dasein reaches outside itself. It is for this reason that Heidegger uses the term "ex-sistence", relational ecstaticity.

\section{From realism to the existential}

Notwithstanding the continuity explored in the previous sections, it is necessary to grasp also the radical differences between pros ti and Mitsein.

Heidegger's world is not an already constituted plurality but what constitutes itself thanks to the intentional character of the Dasein. The world is not an ensemble of entities but the world (Zustand) in which the totality of the entity posits itself. This operation can be done in different ways: there are therefore different worlds. Epistemology does not predicate upon a pre-constituted ontological domain: it is not possible to define subject and object as discrete, self-contained

11 M. Heidegger, Sein und Zeit, GA II, p. 42. 
instances, and knowledge as a relational operation connecting them. On the contrary, relation is what originally constitutes both subject and object. The pros ti is not a moment of the kat'autò but what constitutes the kat'autò. In this perspective it is possible to notice a fundamental discontinuity between Plato and Heidegger - a discontinuity which marks the passage from a realist to a phenomenological-existential approach, and which has been underlined by Heidegger himself in his observations concerning the inner limitation of Greek ontology.

The Mitsein can be defined as our being together with one another in the world. This definition immediately brings into play ethical implications. The passage from the "realism" of the pros ti to the "experiential" of the Mitsein enables us to approach immediately the field of reflection concerning the relational structure of reality and the specific modalities through which relations are established both among human beings and between human beings and things, the Dasein and its environment. The Dasein is in fact an In-der-Welt-sein (Being-in-the-world), and a Mitsein, a being with. "With" expresses here an existential: as the Dasein is essentially a Mitsein, it encounters other Dasein.

Also in the ancient world the ontological dimension has an ethical and political valence; however in Heidegger the ontological structure of the Mitsein is immediately ethical, due to its experiential essence. For Heidegger this ethical meaning implies also a critique of the contemporary situation: the relations that human beings establish with things are instrumental, those established with other human beings are inauthentic. The inauthenticity of relations is caused by the inability to recognize otherness in the other: the undifferentiated "they" defines what is valid for everyone and no-one.

The relational structure outlined by Heidegger is not oriented towards a romantic hen kai pan or a Spinozian pantheism - on the contrary, the principle of identity is precisely what is responsible for the inauthenticity of relations. An authentic relation can be realized only by preserving the radical difference between self and other. As a further avenue of reflection, it is possible to point out how the strands of feminist thought inspired by Heideggerian philosophy - Luce Irigaray can 
be mentioned here as a foremost example - will formulate the catchphrase "thinking the difference" to effectively signify the irreducibility of two wholes, in this case the masculine and feminine.

The relation implied by the Mitsein is not, therefore, a relation between imperfect parts necessitating one another in order to be complete; it is rather a relation between two fully constituted wholes. Also from this perspective it is possible to grasp a profound chasm separating Heidegger's approach from Plato's philosophy as expressed in the Sophist and other works. The concept of relation for Heidegger does not entail a strife for re-constituting an ancient nature, lost due to an original scission (we are referring here to the speech by Aristophanes in the Symposium), it is not what enables an organic image of the whole, where each part absolves its task (e.i. the constitution of the soul and the state in the Republic or the cosmos in the Timaeus); it is rather a shared space whereby the decision to act authentically bears an existential import.

\section{Mitsein and appearing}

John Sallis maintains that "the having in common" of the kinds is "a showing of themselves in community"12. Arguably, the revealing aspect characterizing the communication of the kinds is due to the transcategorical valence of the Different. In other words, the whole process is enabled by the revealing aspect of negation (hence the key meaning of the heteron as pros ti). The identity of relation and appearing is also a characterizing feature of the Dasein. The intentionality of the Dasein constitutes itself as an opening of spatiality: Erschlossenheit. ${ }^{13}$

The $D a$ constituting the existential being-there of being is what determines this aspect of openness.

12 J. Sallis, Being and Logos. Reading the platonic dialogues, Bloomington and Indianapolis: Indiana University Press, 1996, pp. 505-506. For a phenomenological reading of the Sophist cf. A. Vasiliu, Dire et voir. La parole visible du Sophiste, Vrin, Paris 2008; L. Candiotto, "The Children's Prayer: saving the Phenomena in Plato's Sophist", ANAIS DE FILOSOFIA CLÁSSICA, vol. V no 9, 2011, p. 77- 85. ISSN 1982-5323, http://www.ifcs.ufrj.br/ afc/

13 M. Gilbert, Living Together: Rationality, Sociality and Obligation, Rownamm \& Littlefield, Lanham 1996. 
The opening is intended as light, as manifestation of being. However, Heidegger does not refer this process uniquely to a manifestation of the physis: he approaches rather the opening in its existential acception, thus as comprehension (Verstehen) and feelings (Befindlichkeit). In other words, Heidegger refers here to the modes of appearing of relations among human beings, and between human beings and things.

Heidegger proposes here an ontological conception of appearing. However, whilst using a key term of classic ontology, he is not assuming the same realist position predicated by the theorein. The main concern underpinning Heidegger's position is rather to demonstrate how the ontological dimension is the existential. In this perspective, the manifestation of relations among human beings and between human beings and things is always informed by the particular way in which such relations are established, which is not neutral but marked by comprehension and feelings. For this reason Heidegger defines the element characterizing every human action as care. This concept represents even more clearly the existential aspect of the Mitsein: it does not necessarily aim to endow relatedness with a positive character (the "care" of an object implies often its technical employment) but rather to emphasize its experiential component.

\section{Negation as refusal of the "they"}

In Brief über den "Humanismus" Heidegger identifies the cause of the existence of being in the Verfallen, the forgetfulness of the meaning of being, and presents the remembrance (Erinnerung) of the truth of being as the main condition for an authentic existence.

By focusing on the first Heidegger, and in particular on the relation between his lectures on the Sophist and Sein und Zein, it is arguably possible to individuate the origin of inauthenticity in the inability to recognize differences within relations. In other words, I propose to consider the heteron as the defining feature of both pros ti and Mitsein. 
Due to the original "not" which constitutes the heteron, the relation is not a mere identification of differents. The "not" does not imply absence of relation or separation, but indicates a distance that is necessary in order for every-thing to maintain its nature. It is for this reason that Heidegger, commenting on the Sophist, argues that the "not" reveals the thing itself. In fact, the "not" allows the thing to be finite and complete in itself. However, in Heidegger's ontology, this does not imply returning to a metaphysics of presence but recognizing that the relation which is constitutive of the world creates objects which are finite and complete. Moreover, it also implies preserving the finitudedeterminateness of things without subsuming them in an undifferentiated whole.

Accordingly, Heidegger's approach enables us to grasp a relatedness which does not deny difference in view of a greater, complete relational whole, but which, thanks to negation, affirms the determinateness of every-thing within its very relational constitution. The being of any self is constituted by its not-being what is other than itself. Being and Otherness do not exist independently, but constitute themselves thanks to this relation of negation.

\section{Conclusion: ancient and contemporary Heidegger. From Greek philosophy to social ontology.}

Arguably, in order to comprehend Heidegger's existential perspective, it is also necessary to grasp the practical significance of the theoretical positions delineated in the previous sections, moving perhaps beyond the author's own intentions. How should we understand the effort of letting the other be in its own difference?

Heidegger delineates an existential situation in which most relations are inauthentic, and individuates its cause in the indifference characterizing technical domination. If mere indifference creates the anonymity of the "they", where things become objects of domination, then the recognition of difference requires a space where it is possible 
to seek an authentic relation with the other as different, to recognize the other as a subject rather than an object. A change of perspective of this magnitude bears consequences in a number of domains: it concerns not only human relations but also the relations between human beings and the environment. Therefore it presents implications which are not only philosophical but also ethical and political.

Framed from this perspective, the concept of distance appears tightly connected to that of negation. However, negation is here something different from separation-opposition - as explained by Plato in the Sophist ${ }^{14}$, and as emphasized by Heidegger in the passage under analysis ${ }^{15}$, the heteron is what establishes relations, thereby manifesting distinction. This type of negation represents an unusual instance within the history of western philosophy ${ }^{16}$ and requires, to be comprehended, a horizon of ontic relatedness grounded in an ethical moment of the recognition of otherness. The ethical foundation of ontic relatedness endows the classic concept of pros ti and the Heideggerian Mitsein with a propulsive aspect of commitment towards the creation of authentic relations grounded on the notion of Difference.

If we define social ontology as a discipline investigating the statute of the relation which human beings entertain among themselves and with the environment, then it is possible to maintain that the analysis conducted so far demonstrated how Heidegger was also a social ontologist. The Dasein, in its being instantiated in reality, is the true social agent which finds in the Mitsein its particular form of action.

Moreover, in this perspective, Heidegger's Mitsein represents a fundamental contribution for social ontology. Margaret Gilbert ${ }^{17}$ considers the pronoun "we" as the main indicator of social action, which

\footnotetext{
14 Plato, Soph. 257 b9-c3.

15 For a study on the Heideggerian interpretation of this passage, cf. L. Candiotto "The heteron as relational being. Heidegger's interpretation of Plato's Sophist 257b-259d", D. De Brasi, M. Fuchs (eds.), Sophistes. Der platonische Dialog und Heideggers Marburger Vorlesung (WS 1924/25), Duncker \& Humblot Verlag, Berlin 2014 (forthcoming).

${ }^{16}$ For an investigation on the conception of negation in the history of western philosophy cf. L. V. Tarca, Differenza enegazione. Per una Filosofia Positiva, La città del sole, Napoli 2001.

17 M. Gilbert, Living Together: Rationality, Sociality and Obligation, Rownamm \& Littlefield, Lanham 1996.
} 
implies a "plural subject" ${ }^{18}$ and not a simple sum of two or more individuals. Accordingly, the analysis focusing on the particular form of relatedness instantiated by the Mitsein should prompt us to investigate further the relation between the parts constituting the "we". In other words, Heidegger's approach invites us to treat the mereological foundation of social ontology.

The "plural subject", however, stems from a common choice. Arguably, also this aspect is consistent with Heidegger's thought, in particular concerning the central role of the decision for the ontic establishment of relation.

As conclusion I would like to emphasize the contemporary relevance of Heidegger's approach, both for its potential applications to the field of ethics, and for contemporary research in the domain of the metaphysics of relations. Interestingly, this relevance emerges particularly within a dimension of inquiry that Heidegger assimilates from ancient philosophy. In Heidegger's philosophy the ancient and the contemporary can thus establish a fertile relation, whilst maintaining their radical difference.

\section{References}

Heidegger's works cited:

Platon: Sophistes. Marburger Wintersemester 1924/25, GA XIX.

Sein und Zeit, GA II.

Wegmarken, GA IX.

AMBUEL, D. Image and Paradigm in Plato's Sophist. Las Vegas: Parmenides Publishing, 2006.

ARDOVINO, A. Heidegger. Esistenza ed effettività. Dall'ermeneutica dell'effettività all'analitica esistenziale (1919-1927). Milano : Guerini e Associati, 1998.

18 M. Gilbert, On Social Facts, Princeton University Press, Princeton 1989, p. 306. 
BANCALARI, S. L'altro e l'esserci. Il Problema del «Mitsein» nel pensiero di Heidegger. Padova: Cedam, 1999.

BOUTOT, A. L'interprétation heideggerienne du Sophiste de Platon. AUBENQUE, P.; NARCY, M. (Eds.). Etudes sur le Sophiste de Platon. Napoli: Bibliopolis, 1991. p. 535-559.

CANDIOTTO, L. La traccia della negazione. Per un'ontologia delle relazioni a partire dall'olismo severiniano. S. Sangiorgio, M. Simionato, L. V. Tarca (eds.). A partire da Severino. Saggi di ontologia e metafisica. Aracne, Roma 2016, p. 71-105.

CANDIOTTO, L. Il negativo è anche positivo. La trasfigurazione della negazione tra immediatezza e mediazione. MARCATO, L. (Ed.). Forme della negazione. Un percorso interculturale tra Oriente e Occidente. Milano: Mimesis, 2015. p. 161-178.

CANDIOTTO, L. Platone e la metafisica delle relazioni, in CANDIOTTO, L. (Ed.). Senza dualismo. Nuovi percorsi nella filosofia di Platone. Milano-Udine: Mimesis, 2015. p. 73-93.

CANDIOTTO, L. Negation as Relation. Heidegger's interpretation of Plato's Sophist 257 b3-259 d1, D. De Brasi, M. J. Fuchs (Eds.). Sophistes. Plato's Dialogue and Heidegger's Lectures in Marburg (1924-25). Cambridge Scholars Publishers, Newcastle 2016.

CORDERO, N. L. “Introduction”. in N. L. Cordero (Ed.). Platon: Le Sophiste, GF Flammarion, Paris 1993, p. 11-65.

DIXSAUT, M. La negation, le non-être et l'autre dans le Sophiste, in P. Aubenque, M. Narcy (Eds). Etudes sur le Sophiste de Platon. Napoli: Bibliopolis, 1991, p. 167-213.

GALANTI G. S. Esistenza e mondo. L'ermeneutica della fatticità in Heidegger (1919-1927). Padova: Il Poligrafo, 2002.

GALANTI G. S. Heidegger e il problema dell'altro. Milano-Udine : Mimesis, 2006. GONZALES, F. J. Plato and Heidegger. A question of Dialogue. The Pennsylvania State University Press, University Park 2009. 
HYLAND, D. A. Questioning Platonism. Continental Interpretations of Plato. Suny Press, Albany 2004.

IRIGARAY, L. Éthique de la différence sexuelle. Paris: Éditions de Minuit, 1983.

LE MOLI, A. Heidegger e Platone. Essere, Relazione, Differenza. Milano: Vita e Pensiero, 2002.

LE MOLI, A. Novecento platonico. Ontologia della relazione e dialettica dell'intersoggettività nelle interpretazioni contemporanee del platonismo, Annali della Facoltà di Lettere e Filosofia dell'Università di Palermo, Palermo 2005.

NANCY J. L. Of Being-in-Common. Community at loose ends, 1991. p. 1-12.

O'BRIEN, D. Le non-être. Deux études sur le Sophiste de Platon. Saint Augustin: Akademia Verlag, 1995.

OLAFSON F. A. Heidegger and the Ground of Ethics. A Study of Mitsein. Cambridge University Press, 1998.

PARTENIE, C.; ROCKMORE T. Heidegger and Plato. Toward Dialogue. Northwestern University Press, Evanston, 2005.

ROSEN, S. Plato's Sophist. The Drama of Original and Image. New Haven and London: Yale University Press, 1983.

ROSEN, S. Il soggetto e la tecnica. Heidegger interprete "inattuale" dell'epoca presente, Bulzoni editore, Roma 1977.

RUGGENINI, M. (Ed.), Heidegger e la metafisica. Genova: Marietti, 1991.

SALLIS, J. Being and Logos. Reading the platonic dialogues. Indiana University Press, Bloomington and Indianapolis, 1996.

SALLIS, J. Essere e Relazione. Bologna: Il Mulino, 1986.

SASSO, G. L'essere e le differenze. Sul «Sofista» di Platone, Il Mulino, Bologna 1991.

SCALTSAS, T. Relations as Plural-Predications in Plato, Studia Neoaristotelica. V. 10, N. 1, p. 28-49, 2013. 
SCHÜßLER, I., “Le Sophiste de Platon dans l'interprétation de Heidegger”, J.F. Courtine (Ed.), Heidegger 1919-1929: De l'herméneutique de la facticité à la métaphysique du Dasein, Vrin, Paris 1996, p. 91-111.

TARCA, L. V. Differenza e Negazione. Per una filosofia positiva, La città del sole, Napoli 2001.

VASILIU, A., Dire et voir. La parole visible du Sophiste, Vrin, Paris 2008.

VITIELLO, V. Di là dall'evidenza, verso l'ombra. Heidegger interprete di Platone, Il Pensiero, p. 65-84. 1982.

VOLPI, F. (Ed.), Platonismo ed Aristotelismo come figure archetipiche della metafisica in Heidegger, Bianco, F. (Ed.). Heidegger in discussione. Milano: Franco Angeli, 1992. p. 242-273.

Recebido: 07/11/2015

Received: 11/07/2015

Aceite: $14 / 12 / 2015$

Approved: 12/14/2015 